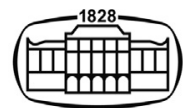

AKADÉMIAI KIADÓ

\title{
Peak-experience and the entheogenic use of cannabis in world religions
}

\author{
MARK S. FERRARA*
}

Journal of Psychedelic Studies

4 (2020) 3, 179-191

DOI:

$10.1556 / 2054.2020 .00122$ (c) 2020 The Author(s)

\section{RESEARCH ARTICLE}

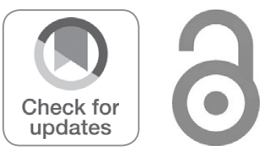

*Corresponding author. Tel.: +16074362427 E-mail: mark.ferrara@oneonta.edu

\section{AKJournals}

State University of New York, 108 Ravine Parkway, Oneonta, NY, 13820, USA

Received: November 13, 2019 • Accepted: April 30, 2020

Published online: July 17, 2020

\begin{abstract}
This paper demonstrates that cannabis can evoke "peak-experiences"-the name psychologist Abraham Maslow gave to fleeting moments of expanded perception indicative of self-transcendence-when used alongside more traditional religious practices such as meditation, fasting, contemplative prayer, and sacramental ritual. For that reason, religious seekers around the globe have deployed cannabis as a deliberate psychoactive to trigger the peak-experiences that stir feelings of ecstasy, wonder, and awe and resolve the "dichotomies, polarities, and conflicts of life." As such, peak-experiences exemplify a form of spiritual revelation that has played a pivotal role in the history of religion, and because of its ability to elicit unitive consciousness at the heart of mystical insight, cannabis has been utilized as a mild entheogen across culture and tradition for millennia.
\end{abstract}

\section{KEYWORDS}

cannabis, world religions, peak-experiences, entheogens, psychedelics, Abraham Maslow, shamanism, mysticism, self-transcendence, hierarchy of needs

\section{MASLOW'S CONCEPT OF PEAK-EXPERIENCE}

Although possessing notably milder psychoactive properties than other psychedelics, such as psilocybin and mescaline, cannabis has a long history as an entheogen in the religious and curative traditions of Asia, the Middle East, Africa, and the Americas. Entheogens help seekers to "discover God within" by acting as "universal keys that unlock the door within each of our minds to other forms of consciousness" (Richards, 2015, p. 23). For millennia, human beings have used cannabis alongside more traditional spiritual practices (meditation, prayer, chanting, fasting) as a vehicle for spiritual or peak-experiences. Renowned psychologist Abraham Maslow defines peak-experiences as "mystical," "transcendental," "self-transcendent," "psychedelic," or "unitive" moments that are driven by a tremendous concentration that does not ordinarily occur. In such a state of consciousness, the truest and most total kind of perceiving takes place as human cognition becomes "non-evaluating," "non-comparing," and "non-judging" of its own volition and rests quietly in heightened awareness (Maslow, 1964, pp. 60-61). In peak-experiences, we become more detached, more objective, and more capable of perceiving the world more truly as a result of relative egotranscending, self-forgetting, egolessness, and unselfishness (Maslow, 1964, p. 62). Peak-experiences, Maslow observed, occur across time, culture, religious tradition, economic class, and gender, and they are essentially incommunicable, unstructured, self-validating, beatific moments that can permanently change one's attitude toward life (p. 75).

While they contain "ethnocentric phrasings" that ground them in time, place, and culture, the ineffable that peak-experiences open towards is universal and accessible to anyone at any time (Maslow, 1964, p. 72). The world perceived in peak-experiences is regarded as good and desirable, and as a result such moments of expanded perception often result in a greater acceptance of all aspects of life, including those once rejected as unwelcome (Maslow, 1964, p. 64). Feelings of gratitude, humility, wonder, awe, reverence, and surrender accompany peak 
consciousness, and the conception of heaven that emerges from them "is one that exists all the time all around us, always available to step into for a little while at least" (Maslow, 1964, p. 66). The sense of the sacred in the everyday that peak-experiences give rise to make one more loving, accepting, spontaneous, honest, and innocent. When these unitive experiences have such immediate aftereffects, they produce profound religious conversions that have lasting therapeutic effects (Maslow, 1964, pp. 66-67).

Recognizing their centrality to mental and physical health, Maslow made peak-experiences an important marker of self-actualization, the impulse to realize one's full potential. Readers familiar with his theory of the hierarchy of needs will recall that self-transcendence sits atop a pyramidic structure (supported by a pattern of motivations whereby an individual's physiological, safety, belongingness, and self-esteem needs are met prior to self-actualization). Religious communities whether formally monastic or informal support systems (such as Catholic Hospitality Houses) can help fulfill "deficiency needs" by providing food and shelter, protecting physical and psychological safety, satisfying love and belongingness needs, and increasing selfesteem through expressions of confidence and competence and service to others (Duncan, 2011, p. 333). Maslow found that self-actualizers-healthy, creative, and resilient people-shared one feature in common: they reported having mystical peak-experiences that resulted in more efficient perceptions of reality, spontaneity, task-centeredness, autonomy, acceptance of self and others, appreciation of life's basic goodness, and comfort with solitude (Steindl-Rast, 2014, pp. 385-386). By facilitating peak-experiences, entheogens may contribute to the motivation to move beyond basic needs and to strive for self-betterment (SteindlRast, 2014, p. 381).

As his work progressed, Maslow added self-transcendence as a possible peak category in light of the reports that he collected from his patients, including children and adolescents, of intense peak-experiences, without them first moving through the expected stages of his hierarchy. In the wake of that revelation, he expanded the hierarchy of needs to include - in addition to biological, safety, belongingness, and esteem deficiency needs-cognitive needs (knowledge, meaning), esthetic needs (beauty, balance), self-actualization needs (person growth, morality, creativity), and self-transcendence (Scott and Evans, 2010, 144). In adding self-transcendence and other growth needs to his hierarchy, Maslow made clear that self-actualization is not enough for a full picture of the optimally functioning human being. He therefore postulated that people who exhibited Being-cognition, and seemed to have gone beyond self-actualization, operated from a higher state of motivation (Koltko-Rivera, 2006, p. 304). In other words, one could be self-actualizing and "healthy," yet still not experience Being-cognition (the ego transcending and self-forgetting that facilitates open-mindedness and a feeling of oneness with the universe).

Individuals satisfied with self-actualization sans Beingcognition were, according to Maslow, functioning on a "lower" or "lesser" level than those motivated to seek Being- cognition (since pain, illness, fear, dissociation, neuroticizing, or any other such forces diminish us, pathologize us, and make us regress) (Koltko-Rivera, 2006, p. 305). Consequently, transcendence for Maslow "refers to the very highest and most inclusive or holistic levels of human consciousness, behaving and relating, as ends rather than means, to oneself, to significant others, to human beings in general, to other species, to nature, and to the cosmos" (Maslow, 1971, p. 269). Maslow predicated his psychology of religion on the premise that mystical or peak-experience is at the core of all religions - and that even the need for religion may represent an attempt to achieve freedom from feelings of anxiety and distress through self-transcendence (Maslow, 1954, p. 34). The question of the place of religious practice in satisfying Maslow's hierarchy of needs and measuring the motivational drive for religious behavior is challenging work that needs further verification, but it may account for the universality of religious practice across time and culture (Brown and Cullen, 2006, 100). Maslow asserted in the posthumous publication The Farther Reaches of Human Nature (1971) that self-actualized and self-transcending individuals are not governed by the rules of society, but by the laws of their own character. By essentially rising above selfactualization, such individuals move beyond "merely healthy people" and exhibit many features attributed to religious mystics-namely transcendence of culture, of time and space, of dichotomies and polarities, of fear, of basic needs (by becoming meta-motivated), and of one's own will ("not my will be done but Thine"). Thereby, peakers learn "to live in the realm of Being" (Maslow, 1971, pp. 262-265). For such people, religion becomes "a state of mind achievable in almost any activity of life, if this activity is raised to a suitable level of perfection" (Maslow, 1971, p. 179).

Maslow believed that psilocybin, mescaline, and LSD might produce peak-experiences in some individuals under the proper circumstances, and he left open the possibility that they might be employed to bridge the chasm between more mystically minded "peakers" and those caught more firmly in the grip of egoic thinking and institutional imperatives $(1964,27)$. Maslow's psychological account of peak-experience and self-transcendence provides a secular and scientific entry point for a study of cannabis in religious and therapeutic traditions around the world, for Maslow ascertained that individuals in whom peak-experiences unfolded could be cured of "chronic anxiety and neurosis," "existential meaninglessness," and even "obsessional thoughts of suicide" (1964, p. 64). In such people, the herenow takes on added import, thereby allowing them to live more fully from the creative center of being without fretting, striving, or yearning. The later version of Maslow's hierarchy of needs model makes self-transcendence a motivational step beyond self-actualization where the self/ego and its needs are transcended in favor of service to others or some higher force or cause conceived of being outside the personal self and beyond personal benefit, such as the furtherance of some greater cause (Koltko-Rivera, 2006, p. 305). This essay identifies a history of cross-cultural cannabis use to elicit peak-experiences and shows how those moments of 
expanded perception were contextualized in a variety of spiritual and curative traditions. Although clinical data concerning marijuana as a trigger for peak-experiences is limited, one analysis of the scientific literature pertaining to the relationship between psychoactive substances and alternate states of consciousness found that cannabis correlated significantly with shamanic and mystical experiences (Luke \& Kittenis, 2005, p. 319).

\section{CANNABIS IN SOUTH AND CENTRAL ASIA}

To demonstrate that humanity has for millennia used cannabis as an entheogen to trigger peak-experiences-and that in their truest form these chemically induced religious experiences are indistinguishable from naturally occurring mystical states of consciousness brought forth by meditation, prayer, and other "religious" activity, we begin in India during the Vedic period (c. 1700 BCE to $600 \mathrm{CE}$ ). Cannabis grows naturally in India, China, Persia, and throughout Central Asia, and it is a rugged, edible plant that provided an important dietary supplement for people living in harsh conditions. The leaves, flowers, and seeds of the cannabis plant have been used by human beings for at least 4,500 years, and cannabis was cultivated as a medicine as early as 900 BCE (Kuddus, Ginawi, \& Al-Hazimi, 2013, p. 736).

In South and Central Asia, the use of cannabis precedes the advent of written record keeping and was firmly established long before the development of institutionalized religion-at a time when magic, mythology, healing, and sacrament blended seamlessly in shamanism, the oldest religious and spiritual tradition known to humankind. The origin of the term shaman is still disputed, but scholars frequently trace it to the Tungus (Evenki) word saman ("one who is excited, moved, raised"), and it is likewise linked to the Sanskrit word sramana ("ascetic") (Znamenski, 2007, pp. 15-16). Shamans serve in many social capacities (including physician, priest, oracle, herbalist, scientist, rhapsodist, storyteller, and mythmaker) - and they cultivate states of consciousness associated with mental and physical healing and gather herbs such as cannabis as catalysts for self-transformation (Rätsch, 2001, p. 15). In the Yanghai Tombs near Turpan in Central Asia, excavations resulted in the discovery of a 2700-year-old grave of a Caucasoid shaman whose accoutrements included a large cache of superbly preserved cannabis, presumably deployed as a medicinal or psychoactive agent or as an aid to divination-thus providing some of the oldest documentation of cultivated cannabis as a pharmacologically active agent (Russo et al., 2008, p. 4171). Cannabis production seems to have been continuous in the region for thousands of years, and the area around the Tarim Basin remained a major cannabis producing center until the 19th century (Peri, 2016, p. 141).

In addition to deploying herbs like cannabis as one facet of holistic healing, shamans use the repetition of vocal and instrumental sound, manipulation of the breath, fasting, and prolonged sexual abstinence to help them enter trance states (Glosecki, 2004, p. 196). The loss of ordinary patterns of time and space and a radical realignment of perception, often culminating in some form of symbolic death and resurrection, are among the shifts in consciousness evoked by shamanic techniques of ecstasy (McKenna, 1992, p. 7). The ancient shamanic practices of journeying in search of a lost soul as a modality of healing appears in the Rig Veda, one of the oldest religious texts in any Indo-European language (Robinson, 2014, pp. 51-53). It remains difficult to know with certainty when Hindus first settled in the Indus river valley, since their relationship to the earlier Indus Valley Civilization is unclear. At the height of its prosperity between $2600 \mathrm{BCE}$ and $1900 \mathrm{BCE}$, it spanned 3,000 square miles in northwest India and Pakistan (Robinson, 2014, p. 35). The Hindus who succeeded the inhabitants of the Indus Valley Civilization did not identify with the material culture of their forbearers, instead they venerated the Vedas and built grand temples to their gods.

The chief deities of the Rig Veda were personified as forces of nature (sun, fire, wind, sky, rain), and they were the foci of regular ritual sacrifices-as were other principal gods, including Varuna (guardian of sacred laws and the divine order), Prajapati (lord of creatures and the primeval person whose dismemberment creates the phenomenal world), Agni (the fire god who consumes the sacrificial offerings and conveys them to the gods), Yama (the god of death who looks after the souls of the departed), and Soma (the god of a tonic of eternal life pressed from a psychedelic plant) (Robinson, 2014, pp. 53-54). The Soma Mandala that makes up the Ninth Book of the Rig Veda features more than 100 similar dedications to soma pavamana, the purifying soma, as a means of winning "heavenly light" and "all felicities" (Doniger, 1981, pp. 134-35).

In the early Vedic Samhitas, ("collections" of mantras and praises to God), heroic visionary rishis (Hindu saints) engaged various gods and powers thought to pervade the world in a quest for self-transcendent experiences assisted by ascetic practices and the ingestion of "soma," a mysterious beverage whose exact constituents are unknown, but which may have included cannabis (Clarke \& Merlin, 2013, p. 224). Like the shamans before them, Vedic Brahman priests prayed for individuals, ensured the collective welfare by warding off spirits, cured diseases, helped to defeat enemies, and brought wealth and prosperity to their communities. Ensuring peace and harmony-and providing a path for the development of human consciousness beyond the ego-were also credited to Brahmanic rites (out of which grew yoga and the belief in individual paths to salvation) (Frawley, 2001, pp. 163-66).

The hymns in the Atharva Veda include the imprecations, blessings, prayers, and magical spells of the type frequently discoverable in popular superstitions. Compiled sometime later than the Rig Veda but likely before 1000 BCE, the Atharva Veda contains some of the oldest references to the ritualistic use of cannabis, and it preserves ancient shamanistic rites dealing with village concerns, individual well-being, and the use of magic hymns to "control" all elements of nature (Frawley, 2001, pp. 176-177). The Atharva Veda mentions cannabis as one of the five sacred plants and asserts that a guardian angel resides in its leaves 
(Touw, 1981, p. 25). Book Two of the Atharva Veda features a hymn to win protection from injury, to ensure good health, and to bring prosperity, and it is rendered effectual by wearing a charmed amulet. In that incantation, cannabis is lauded as a panacea for rheumatism and a variety of other ills. Mostly obscure to the modern non-specialist, the hymn asks, "May Cannabis and [other herbs] preserve me from [illness]... and prolong the years we have to live" (Griffith \& Abhimanvu, 1962, p. 46). Practitioners of this ancient religious tradition utilized cannabis as a medicinal herb, and because of its centrality to charms and spells, cannabis was regarded as a "sacred grass" for its power to vanquish sickness, despair, and calamity (Campos-Costero, 2006, p. 19). During certain rites hemp boughs were thrown into a fire "to overcome enemies" and other evil forces. The Vedas also refer to the plant as a "source of happiness," a "joygiver," and a "liberator" (Touw, 1981, p. 25).

As later generations appropriated the Rig Veda, Atharva $V e d a$, and other Vedic scriptures, the transition from Vedic Brahmanism to Hinduism happened almost imperceptibly. Some Vedic gods suffered diminution as others grew in stature (an organic process that continued into the Puranic Ages). Indra, for example, retained his popularity but lost his status as leader of the gods. Conversely, Shiva and Vishnu (along with their female consorts) assumed exceptional positions in what became the Hindu trinity (trimurti) (Eliade, 1982, pp. 45-46). The Lord Shiva was thought extremely fond of cannabis, an affection that earned him the soubriquet the "Lord of Bhang" (a correlate to Indra as the "Lord of Soma"). We realize from the proclivities exhibited by both gods that the peoples of the Indian subcontinent have long understood that plants such as cannabis are essential tools in exploring consciousness. According to the Vedas, Shiva, who rules over the constant cycles of creation and destruction that make up the phenomenal world, lives the life of an ascetic on Mount Kailash. After sampling cannabis flowers on Mount Mandara, another holy site, he brought the plant down from the sacred mountain for the benefit of humankind (Godlaski, 2012, p. 1068). For that reason, Sadhus, or holy mendicants devoted to the ascetic life and to following Lord Shiva, consume large quantities of cannabis flowers and hashish from small clay pipes (called chillums) during rituals of worship, meditation, and yoga (Godlaski, 2012, p. 1069). Yogis (ascetic holy men) and fakirs (mendicant monks) have long smoked cannabis mixed with tobacco to enhance meditation, particularly during Diwali, the Festival of Lights, and the Kumbha Mela festival held every twelve years (Warf, 2014, 421). Even otherwise abstemious Hindus may consume bhang or other cannabis preparations on the occasion of Shivaratri ("Night of Shiva"), and legal cannabis and bhang shops in Varanasi (Shiva's sacred city) operate year-round.

\section{CANNABIS IN CHINA AND TIBET}

Certainly by the fourth millennium BCE, though likely thousands of years earlier, central and eastern Asians used the cannabis plant in the manufacture of hempen thread and rope-and in time that plant became an essential foodstuff in China (as one of the "five grains" together with rice, soybeans, barley, and millet) by the Han dynasty (206 BCE to $222 \mathrm{CE}$ ) (Touw, 1981, pp. 31-32). The Book of Songs, one of the Five Classics of the traditional Confucian canon, offers an idealized portrait of life during the preceding Zhou dynasty (c. 1000 to $250 \mathrm{BCE}$ ). It features folk tunes, songs of the nobility, ritual hymns, and lyrical ballads addressing topics ranging from ancestor worship and the concerns of commoners to the affairs of members belonging to the ruling house (Owen, 1996, p. xv). Several passages in the Book of Songs reference cannabis, due to its centrality to everyday life. In one such poem, the marriage customs in the $\mathrm{Lu}$ and Qi kingdoms (in modern Shangdong province) are highlighted, and the process of negotiating a nuptial agreement is compared to planting hemp (Waley, 1996, p. 80). In one of the Airs of Chen, a vassal state in eastern Henan, a quasimystical vision of a pond by the Eastern gate (which is "good for steeping hemp," "cloth grass," and "rushes") is compared to the beautiful third daughter of the Ji family who has a special talent for capping songs, proverbs, and stories (Waley, 1996, p. 109).

Prior to the Han dynasty, the knowledge of healing herbs was highly esteemed and often furtively passed down through families of practitioners in China. When traditional shamanistic practices were repressed under Han rule, as state authorized religions commanded imperial favor, shamanism merged with religious Daoism as a way to survive. Religious Daoism emphasized ritualistic, ceremonial, and alchemical exercises in which herbal and mineral brews were quaffed in the quest to achieve immortality. Religious Daoists, who trained in alchemy and understood the psychoactive and entheogenic properties of cannabis, undoubtedly knew how to manufacture hemp-based incenses and elixirs for ceremonial rituals. Although references to cannabis in Daoist literatures are rare, the custom of burning the plant to drive away evil spirits is featured in the sixthcentury literary anthology Essentials of the Matchless Books ( Wu Shang Pi Yao). The smoke from Daoist incense burners would also have had a salutary effect upon people gathered together on ceremonial occasions, and religious Daoists often combined herbal medicines with meditation and other exercises to effect spiritual transformation (symbolized in the alchemical transmutation of base metals into gold).

Visitors, merchants, mendicants, and doctors have traversed the mountains and valleys of the Tibetan plateau for thousands of years, and they left behind knowledge of their religious, medical, and cultural traditions, which mixed (sometimes seamlessly) over time with indigenous shamanistic and animistic Bon traditions. This intersection of traditions in Tibet made possible the formulation of a unique form of Buddhism known as Vajrayana (or Tantra). The word Tantra connotes a "weaving together" of Indian Vedanta, Shaivite Hinduism, and a pantheon of Bon deities with an arcane knowledge of medical herbs. While Chinese contributions to Vajrayana medicine were significant, they 
remained secondary to those of Ayurveda. Botanicals, however, played an important role in both Chinese and Ayurvedic medicine, and the abundance of cannabis growing wild in the Tibeto-Himalayan region meant that the healing herb was readily accessible. Its seeds were used to make cooking oil, but the remaining parts of the plant were dedicated to the treatment of skin and lymph disorders, the repair of slow healing wounds, and the maintenance of overall vitality. Other common applications of cannabis in Vajrayana medicine include the treatment of paralysis of the tongue, convulsions, breaking up phlegm, and the termination of delirium during fever (Touw, 1981, pp. 31-32).

Tantra, as a relatively coherent set of techniques and practices (including deity visualizations and mandala, rituals associated with cremation-grounds and polluting substances linked to sex and death, and internal yogic exercises intended to achieve health, longevity, and liberating insight) appear more or less complete by the ninth century (Samuel, $2008,9)$. This use of ecstatic religious practices and magic ritual has led to speculation that Vajrayana originated in India and is associated with the Vedic soma cults that preceded it. In this way, Tantric practitioners may lay claim to a legacy of cannabis use that begins with references to bhang in the Rig Veda and Atharva Veda. This identification with sacred Indian traditions is so great that Tantric scripture is sometimes referred to as the "Fifth Veda" (the Atharva Veda being commonly regarded as the fourth) (Aldrich, 1977, pp. 227-228). The author of Yogaratnamala, a Tantric work dating from the twelfth century and attributed to the Buddhist philosopher Nagarjuna, recommends the smoke of the cannabis plant to thwart one's enemies (Meulenbeld, 1989, p. 64). Tantric texts are also characterized by their preference for peculiar sets of names for cannabis (such as trailokyavijaya and sakrasana), but Meulenbeld notes the usage of some 43 synonyms for bhanga that add to the difficulty of definitively tracing the history of cannabis in India and Tibet (1989, p. 66-67).

In their emulation of Indian Tantra, some Vajrayana Buddhists consumed bhang to lower inhibitions during occult sexual exercises believed to facilitate religious awakening. Followers of Buddhist Tantra (sometimes known as esoteric Buddhism) integrated established Indian practices such as mantra, mandala, fire sacrifices, and soma and cannabis consumption and developed them into a comprehensive religious system (Orzech, 2011, pp. 5-6). In Buddhist Tantra, cannabis is sometimes taken in the context of meditative rituals to facilitate peak consciousness. A large dose, taken orally, ensures increasingly heightened awareness from the beginning of the ritual onwards, with the greatest "high" coinciding with the climax of the ceremony (Touw, 1981, p. 25). Cannabis also became an important part of "Tantric religious yoga sex acts consecrated to the goddess Kali," during which the devotee uttered the following mantra before a bowl of bhang: "O ambrosiaformed goddess who has arisen from ambrosia, who showers ambrosia, bring me ambrosia again and again, bestow occult power [siddhi] and bring my chosen deity to my power" (Abel, 1980, p. 20). The potion, made efficacious after uttering several other mantras, heightened the senses and increased a feeling of oneness with the goddess.

The religious and secular use of cannabis is so widespread in the Himalayas that it is often taken for granted (Touw, 1981, p. 26). Nonetheless, Tibetan medical texts describe the miraculous creation of certain plants through the intervention of divinities and religious personages, and Tibetan healers and religious mendicants rely on many plants growing in the wild, including cannabis, to prepare their remedies and to evoke unitive consciousness (Boesi, 2014, para. 5). Such drug triggers for peak-experiences, Maslow observes, are helpful when wisely used to elicit a clear perception of the self and the universe "as an integrated and unified whole," which can "change the person's character and his Weltanschauung forever after" (Maslow, 1964, pp. x \& 59).

\section{CANNABIS IN WEST ASIA AND THE MEDITERRANEAN REGION}

Based on the presence of pollen in the Black Sea from the early Holocene (the name given to the last 11,700 years of the Earth's history), cannabis is likely quite ancient in the northern Iranian mountains, and it's reasonable to assume a long cultural history there (Long, Wagner, Demske, Leipe, \& Tarasov, 2017, pp. 251-252). Some six millennia ago, on the Iranian plateau, a group of Indo-Iranian peoples emerged who made sacrifices to a variety of gods and goddesses, employed a priestly class to oversee those rites, and created a stratified social system that sustained a lifestyle built around the plow. The Avestan language that they used closely resembled Vedic Sanskrit (a consequence of shared IndoIranian heritage out of which Indian and Iranian cultures evolved separately), and that fact helps to account for correspondences between Vedic religious texts and the Gatha sections of the Avesta (or Zend-Avesta), the sacred book of Zoroastrianism. A mixed genre work, the Avesta contains legal, literary, and liturgical writings, in addition to collations of hymns, short prayers, and praise songs used during ritual ceremonies to evoke peak-experiences (Ferrara, 2016, p. 32). Such transcendental moments help reconcile people to "the presence of evil, of pain, of disease, of death" in the world by enabling more "god-like perception, superhuman perception" and by filling them with emotions of "pity, charity, kindliness, perhaps sadness and amusement" (Maslow, 1964, p. 64).

Like their Indian counterparts, the ancient Iranians venerated sky and Earth gods and goddesses, worshiped ancestors, and participated in cults of fire and water (Foltz, 2013, p. 16). Avestan deities maintained a cosmic order based on oppositional forces, and Iranian priests served as libation pourers, keepers of sacred fires, and preservers of powerful chants, charms, and spells. The Gatha sections of the Avesta are contemporaneous with the Rig Veda, and the Zoroastrian deity Mithra exhibits some of the same attributes as the gods Mitra and Varuna in the Rig Veda. At 
some point, a rivalry between the groups emerged and inaugurated a process of scriptural transmission during which some features of early Vedic culture were preserved by Iranian Zarathustrans, while others were reformed or altogether rejected (such as the practice of raiding cattle and the worship of Vedic devas) (Bryant, 2001, pp. 130-131). The prophet Zoroaster (Zarathustra) forever transformed that shared Indo-Iranian tradition by proclaiming the preeminence of the god Ahura Mazda-while diminishing the importance of competing deities and modifying or abandoning certain ritual practices. He reimagined Ahura Mazda as a unitive creative force (whereas before him divine agency was diffuse or unattributable).

From the Gathas, the part of the Zend-Avesta thought to preserve the words of the tradition's founder, we gather that Zoroaster created important roles for himself as an interpreter of religious commandments and bestower of spiritual instruction. Out of these vocations sprang a set of ethics that emphasized the human capacity to choose between good and evil forces in the world (Foltz, 2013, pp. 33-35). Zoroaster believed that an individual's fate was determined by free will, and that after death, the soul made its way to a river of fire where the god Mithra judged every soul based on its thoughts, words, and deeds in the human world. Mithra therefore embodies an ageless notion of justice. During the Last Judgment in Zoroastrianism, at the end of time, Mithra initiates the final sorting of souls according to deed-an event culminating in a celestial haoma (soma) sacrifice that ushers in a restoration of an earthly paradise where death is forever vanquished (Boyce, 2002, p. 28).

The daily duties of Zoroastrian priests revolved around the strict recitation of the Gathas every morning, as well as sections of older Avestan scripture. They were also charged with preparing the yasna sacrifice, and their focus on rituals involving animals and haoma indicate that mystical experiences were evoked through the consumption of plant and fungal substances during sophisticated rituals designed to alter consciousness. Like soma, the exact constitution of the haoma formula remains murky: psychoactive mushrooms, cannabis, ephedra, ergot, and datura are prime candidates for the main ingredients (Ruck, Hoffman, \& Celdrán, 2011, p. 42). There exists little doubt that early Iranians knew the technique of ecstasy through cannabis intoxication, and the importance of that understanding is confirmed by the wide dissemination of the Iranian term for cannabis (bangha and its variations) throughout central Asia, even though the term probably referred generically to several psychoactive plants-including datura (in a similar manner to how soma and haoma were likely constituted from multiple plants). As this religion found itself competing with a host of other traditions (including Judaism, Manicheism, and Christianity) between the fourth and sixth centuries, Zoroastrianism gradually ceded ground to them, but a hallowed place for cannabis in religious practice continued in the Middle East. The first evidence of cannabis being used by ancient Israelites as a deliberate psychoactive during religious ceremonies has recently been found in cannabinoid residue on an altar at Arad shrine (Arie, Rosen, \& Namdar, 2020, p. 12), but that discovery will need to be corroborated.

Another way that people of the ancient Mediterranean world fostered peak-experiences was through initiation into one of several Mystery traditions, which offered important alternatives to state sponsored religions. Participants underwent ritual purifications, wore charmed amulets, and made offerings at shrines to ward off malevolent influences. Mystery cults, generally speaking, drew from a mixture of traditions (including Orientalism) but were most often associated with Demeter (goddess of the harvest), Dionysus (god of wine and theater), and Mithras (i.e. Mithra, god of justice and contractual truth). Mystery rites reached an apex in collective moments of heightened perception, at the center of which were symbolic death and resurrection indicative of peak-experiences. As Maslow observes, "peakexperiences can be so wonderful that they can parallel the experience of dying, that is of an eager and happy dying" (1964, p. 65). The Mysteries of Isis, for instance, required the "voluntary death" of neophytes as a prerequisite to spiritual rebirth (Eliade, 1982, p. 280). Mystery Cults worked at the intersection of religious intoxication and peak-experiencesand they represent a significant attempt by human beings to reach the divine by all means necessary, including the consumption of entheogens such as cannabis. In this respect, the Eleusinian Mysteries echo Vedic soma rites and Zoroastrian haoma rituals, in so far as they esteem religion a living force that must be experienced directly-and not something abstract, symbolic, or representational.

Christianity took root in Egypt within a hundred years of the crucifixion of that tradition's founder, and in that context of religious transition, a sect of early Gnostic Christians took shape that was eventually deemed heretical by a burgeoning ecclesiastical leadership for envisioning God as a supreme oneness (rather than as a trinity or duality); for interpreting the martyrdom of Jesus Christ in metaphorical terms of spiritual rebirth; and for offering initiates "gnosis," knowledge of spiritual mysteries and salvation through personal revelation. Although the Gnostics and their brand of mystical Christianity largely vanished by the late fourth and early fifth centuries in the wake of doctrinal orthodoxy and the rise of Coptic Christianity (sans Gnosticism), a long tradition of desert monasticism endured in Africa that sanctioned religious contemplation in isolation from the world. During this period, many Christian ascetics in Egypt and Ethiopia smoked cannabis from ornamental pipes in order to trigger peak-experiences and to bolster their fortitude during ritual fasts, mortifications, and vigils (Hamid, 2002, pp. xxxii-xxxiii). Even today, during Coptic Christian and Muslim mulids (religious festivals) in Egypt, one discovers a colorful pastiche of Sufi pilgrims who mix with roaming youth and families as they navigate thick markets, sites of ecstatic piety, popular music concerts, hashish (cannabis) corners, and moments of solemn commemoration in saint shrines. Literally meaning "birth," most mulids celebrate a saint's birthday (though many, including those of Coptic saints, take place on the anniversary of a saint's death 
and usually around a saint's tomb-the most sacred focal point of mulid pilgrimages and processions) (Ramzy, 2017, p. 377).

The Arab invasion of Ethiopia resulted in the destruction of more than 3,000 Christian churches, and many Copts were forced to relinquish their faith during the rule of the Fatimid caliphs from the tenth to twelfth centuries. Cannabis, however, remained an important psychoactive agent in the medieval Muslim world, and it continued to be credited with opening deeper levels of perception (Rosenthal, 1971, p. 25). The traditions of tolerance, love, and selfsurrender embedded in Islam gave rise to Sufism, a form of Islamic mysticism emphasizing a personal quest for a direct experience of the divine in the here and now. Broadly speaking, Sufis seek to overcome their lower (egoic) selves by proceeding through stages of spiritual development under the guidance of a master teacher (sheikh) to whom obedience is sworn. Sufi aspirants pursue self-annihilation as part of that quest. While strictly speaking there can be no Sufis before the arrival of Islam, the syncretic nature of Sufism brought together contributions from pre-Islamic asceticism, Zoroastrianism, Mithra worship, monastic Christianity, and Neo-Platonism to create an enduring Muslim mystical tradition that emphasizes love and ecstatic communion with God (Milani, 2013, pp. 8-10).

An injunction against intoxicants in the Quran means that most Muslims eschew alcohol, but cannabis falls into a nebulous area where it is socially accepted by many Islamic groups but disdained or prohibited by others. Even so, the use of cannabis for medicinal, religious, esthetic, and social purposes is well documented. Abu Yazid al-Bistami championed a form of "intoxicated" Islam that drew upon such proverbial wisdom. An ascetic whose grandfather converted to Islam from Zoroastrianism, al-Bistami emphasized achieving "self-annihilation" (fana) in the quest for union with God (Foltz, 2013, pp. 182-183). He experienced intense feelings of "intoxication" in the love of Allah, which led to the death of his egoic self. Borrowing symbolic themes from the Persian court poetry that preceded Islamic literature, he created metaphors of being "drunk" on god, and thereby opened the way for an enduring admixture of ascetic practices and psychoactive intoxicants as a means of achieving ecstatic states of consciousness. Intoxicated Sufis attained divine perception through the repetitive recitation of prayer formulas, the continual remembrance of God, energetic dancing and whirling, and playing or listening to religious music. Writers such as Al-Ghazali rose to defend controversial Sufi religious practices (including the ritual ingestion of cannabis) against attack from the more orthodox forces that would see them abolished as blasphemies.

Whether spontaneously occurring, stimulated by "taking a pill or chewing a plant," or generated through religious practice, peak-experiences offer the possibility of a new way of being. Authentic transcendental experiences enable an "individual to be so peculiarly open and sensitive to organic reality that the ego begins to be seen for the transparent abstraction that it is" (Watts, 2013, p. 88). Peak-experiences, which represent an important response to the panhuman yearning for paradise, must be deepened through spiritual exercises such as meditation to bring presence and mindfulness more permanently to the fore of consciousness. The Sufi insistence on making cannabis part of spiritual practice is attributable to the fact that, in the right-minded person, cannabis facilitates a heightened state of concentration that can deepen contemplation. For Sufis adhering to the "intoxication" school, hashish is a holy sacrament that stimulates mild feelings of euphoria and lends acquiescence and carefreeness. It bestows feelings of jocularity and amiability (Khalifa, 1975, p. 199). These same qualities made the plant popular among Sufis living communally, and they helped to guarantee a space for the creative expression of their musicians, dancers, poets, and artists.

Mystic devotees from Syria during the mid-twelfth century employed cannabis in religious and communal settings to increase sociability, activate intelligence, stir jocularity, and encourage meditativeness (Khalifa, 1975, p. 199). Its prevalence led the thirteenth-century Spanish historian Ibn Sa'id to bewail hashish consumption in Egypt, and his contemporary, the physician Ibn al-Baytar, reported seeing Sufis in that country eating baked cannabis leaves rolled into paste pills (Rosenthal, 1971, pp. 56-57). Though cannabis never received official sanction by institutionalized Sufism, it became an integral part of the life of antinomian dervish communities in Anatolia, as attested to in a story preserved in a fourteenth century Turkish folk-narrative, the Hamzaname (Péri, 2016, p. 147). Perhaps the best measure of the enduring influence of Sufi practices on the Islamic world are the Muslims who still use preparations of cannabis (as bhang, ganja, or hashish) for a variety of purposes in Iran, Afghanistan, Pakistan, India, and kif (alternately spelled "kef," "kief," or "keef") in North Africa-despite prohibitions against intoxicants in the Sharia.

\section{CANNABIS IN AFRICA}

Maritime trade may have carried cannabis from western India to the Arabian Peninsula and eastern Africa by $700 \mathrm{CE}$ (Duvall, 2014, p. 46). It is also possible that Arab merchants brought the plant to Africa via trade routes, across the Red Sea and down the coast of Eastern Africa, during a shortlived but powerful late-medieval world system. From there, it gradually spread to Bantu speakers in the interior and therefore was in use in the Zambezi River valley by the time the Portuguese arrived in 1531. Swahili-speaking traders likely spread it westward (Warf, 2014, p. 424). Morocco also has a long history of cultivation and consumption of kif, a mix of tobacco and dried cannabis, smoked in a pipe called a sebti. In fifteenth century Morocco, the increasing recreational use of cannabis led to the cultivation of the plant on a small scale in many private gardens and orchards (Afsahi and Darwich, 2016, p. 192). As cannabis continued its journey to other regions of the continent, it was blended with native herbs and formed into powders and pastes for eating, inhaling, or smoking. The oldest smoking pipes from 
sub-saharan Africa date from the early fifth century BCE, as much as two millennia before Europeans encountered American Indian pipes packed with tobacco (Duvall, 2019, p. 16). Before cannabis came on the scene, indigenous peoples smoked datura, though a surge in pipe use in eastern African sites after the tenth century may suggest the diffusion the cannabis (Duvall, 2014, p. 46).

Long prior to the introduction of cannabis, plant medicines featured prominently in a wide variety of ritual and medical contexts across Africa, and traditional pharmacopoeias included consciousness-altering substances for the diagnosis and treatment of disease (Rätsch, 2001, p. 129). The Kalahari Bushmen of southern Africa, for instance, possess an extensive knowledge of plants in their immediate environment, and they deploy some of them to alter consciousness to cure the sick, make divinations, and engage in out-of-body travel (Mitchell \& Hudson, 2004, p. 39.) African shamans, native medical practitioners given to mysticism, were authorized by their peers to practice herbal medicine, divination, invocation, magic, and prayer. They administered psychoactive decoctions in the form of enemas, snuff, or oral doses and listened attentively to the uninhibited narratives of medicated patients for clues concerning the origins of their illnesses (Sofowora, 1982, p. 32). Cannabis also found an important place in community rituals designed to evoke spirits of the ancestors and to placate them with its sweet incense.

In southern Africa, the plant is called dagga, in western Africa diamba (or riamba), and in the east-central region of the continent bangi (from the Sanskrit bhanga) (Du Toit, 1975 , p. 81). Such variations in nomenclature provide a unique perspective on the movement of cannabis from India to Africa alongside Arab merchants and religious mendicants. Bantu-speaking tribes-who spread over a vast area from Central to Southern Africa-valued cannabis as a panacea, finding it effectual in treating asthma, malaria, blood poisoning, snakebites, and a host of other maladies. Eighteenth and nineteenth century writers record that the Khoikhoi sometimes consumed canna (taxa), reported to have psychoactive properties, together with cannabis, to create trance and alternate states of consciousness that included flashbacks and visions (Mitchell \& Hudson, 2004, pp. 45-46). Pygmies, the largest and most diverse group of active hunter-gatherers, or forest foragers, consume cannabis from long reed pipes or water bongs fashioned from calabashes or clay before hunts to bolster their vigor and fortitude-and to enhance their musical performances that combine polyphonic and contrapuntal singing with instrumental accompaniment (Fürniss, 2014, p. 209). The savants of Zululand were dagga smokers who burned cannabis flowers through large water pipes. In times of crisis, these sages cured disease and prophesized the future-and perhaps as a consequence of that relationship to sagacity, cannabis continues to be associated with knowledge, discernment, and astuteness in southern Africa (Ferrara, 2016, p. 82).

Generally speaking, Native African peoples believed that ancestor spirits acted in the world of the living, and that death simply marked a transition from one world to the next. Boundaries separating realms of the living, unborn, and dead-like those of the sky, human world, and underworldwere envisioned as highly permeable, and their myths of creation focused around primordial beings who created humankind and imparted the essential skills of hunting and reproduction (Olupona, 2014, pp. 11-17). According to that worldview, every living and inanimate object is holy. Since certain herbs tended to be venerated, a comprehensive understanding of them remained a prerequisite for any diviner or priest (Olupona, 2014, p. 5). In some African religious traditions, one finds a mystical belief in a numinous force that suffuses the cosmos and endows everything with an innate "aliveness," so that rocks and stones pulsate with the same intense energy as every singing blade of grass and dancing bird. When reality is thus conceived as intersecting patterns of energies apprehended subjectively, all things are perceived as localized objects embedded in a web of relationships (Bynum, 2012, pp. 184-85). In African religious and healing practices that undifferentiated life force is thought to be amplified through prayer, invocations, praise songs, music, dancing, and the ritual use of cannabis-and in the peak-experiences that result, "the dichotomies, polarities, and conflicts of life tend to be transcended or resolved," as people are propelled toward "fusion, integration, and unity" (Maslow, 1964, pp. 65-66).

\section{CANNABIS IN THE AMERICAS}

Ample evidence exists for the use of psychotropic plants by several Native American cultures dating from before the Spanish conquest of Mexico (1521-1525). One of the earliest sacred plants was the neurotoxic Sophora secundiflora used by Paleoamericans of the desert of northern Mexico and southern Texas approximately ten thousand years ago (Diaz, 1977, p. 647). Although other colonial attempts at the cultivation of hemp as a fiber for rope, netting, and sails preceded it, in June 1545 the Spanish Crown ordered Viceroys and Governors to "mandate the cultivation of hemp and flax in the Indies" and to "get the Indians to apply themselves to this farming and to weaving and spinning flax" (Campos-Costero, 2006, p. 65-66). Toward the end of the colonial era, the leaves and seeds of the cannabis plant were referred to as pipiltzintzintlis (one of the more notorious names for a hallucinogenic, divinatory substance that fits into a broad category of "hallucinogens"-including peyotl and ololiuhqui-with which Mexico is so phenomenally rich) (Campos-Costero, 2006, p. 96).

Adopted by Native American shamans into a tradition that included the ritual use of psychedelics (such as peyote, DMT, and a variety of mushrooms) to elicit peak-experiences as a modality of healing, cannabis spread throughout North and South America. Some mystical shamanistic sects in North America, such as the Ghost Dance religions, employ séance to determine the cause of disease, expel pathogenic substances creating illness, or locate a lost soul in 
order to restore a person's life force (Eliade, 1964, pp. 298299). Like the Mediterranean Mystery traditions, Native American shamanistic initiations are shrouded in secret rites, but they might involve a candidate's symbolic death and resurrection, ecstatic visits to lands of the Dead or Sky, the insertion of magical substances into the initiate's body, the revelation of clandestine doctrines, and instruction in techniques of curative healing (Eliade, 1964, pp. 314-315).

In cannabis, the Tepehuan Indians of Mexico discovered an occasional substitute for the peyote that they collected for sacrosanct ceremonies (Lee, 2013, pp. 38-39). Bestowing on the plant the sobriquet "Sacred Rose," they attributed to marijuana the ability to stimulate loquaciousness, to enhance social interaction, and to serve as a gateway to religious experience. In some of their rituals (which blended aboriginal beliefs with Christian symbolism), the Tepehuan placed the contents of bundles of paper on an altar. The Sacred Rose would rest there, surrounded by small bells, incense holders, and whistles that served as objects of attention for attendants who made daily offerings or provided ceremonial water refreshments (Williams-Garcia, 1975, pp. 138-40). The Tepecano of northwestern Mexico called cannabis Rosa Maria and occasionally used it as a substitute for peyote (MacRae, 1998, p. 335).

Since it competed with stronger entheogens, including peyote and mescaline, cannabis did not always arrive at the center of religious rites in the Americas, although the Cuna Indians of Panama were known to smoke cannabis communally in tribal meetings, and the Cora Indians in the Sierra Madre Occidental turned to it when indigenous plant herbs became unavailable (Booth, 2005, p. 187). Cannabis seeds may have entered Brazil as early as the mid-sixteenth century from West Africa with victims of the European slave trade, possibly sewn into cloth dolls that were tied to the rag tag clothing worn by slaves (Hutchinson, 1975, p. 174). Several Brazilian religious groups made controlled ritual use of the entheogen ayahuasca to evoke peak-experiences and shamanistic visions. Ayahuasca became a central sacrament in a number of syncretic religions (mixing Catholicism, Spiritism, African religiosity, and Native American shamanism), which originated among Amazonian rubber tappers and then spread to the urban middle classes in Brazil, and later overseas (MacRae, 1998, p. 328). Another sacramental substance also worshiped by the followers of one of Santo Daime's branches is Santa Maria or cannabis. During the "consecration of Santa Maria," ritual participants remained silent while a cannabis cigarette was passed to the person to the right of the last smoker until it was totally consumed. If silence was not kept, the partakers had to at least keep the conversation on a high spiritual level (MacRae, 1998, p. 332).

\section{THE RASTAFARIANS}

Long before Christopher Columbus spotted Jamaica on his second voyage in 1494, the aboriginal Arawak and Taino peoples inhabited the island. The Spanish, in whose name Columbus claimed Jamaica, settled the island for approximately 150 years before the British gained control. During the eighteenth century, Jamaica attracted settlers eager to establish plantations to produce sugarcane, but in order to make their large establishments profitable, colonists required an abundant supply of cheap labor-and so they imported slaves from colonial operations in Africa. Those hapless individuals abducted from their homes and sold into slavery in Jamaica introduced some cultural features of their homelands, including their languages, religions, and musical traditions. They brought art, song, dance, and food traditions related to ceremonial rituals marking the human passage from birth to death too, as well as a respect for elders in the community and a heightened sensitivity to the natural processes of the Earth and cosmos (Ferrara, 2016, p. 89). With the prohibition of slavery on the island in 1834 , plantation owners imported indentured laborers from India and China. Cannabis came to Jamaica with Indian laborers, which explains the widespread use of the Hindi word "ganja" for marijuana. As cannabis circulated through the lower classes of Jamaican society, it infiltrated black communities and gained popularity in the countryside and in the poor districts of larger towns (Boekhout van Solinge, 1996, pp. 12-13).

Due to the logistical challenges of operating large-scale plantation estates requiring skilled workers, British colonists began to educate children of free slaves and indentured laborers to cultivate the land, to keep plantation accounts, and to protect their private property (Deirdre, 1995, p. 103). Despite those advantages over field work, low wages, limits on land ownership, high poll taxes, and widespread racism led to social uprisings, such as the Morant Bay Rebellion in 1865. Although by that time slavery had been abolished for a generation, the ideology of dominance remained rooted in the planter psyche, and stark differences in levels of wealth and power persisted among social classes in Jamaica (Delle, 2014 , p. 232). By 1900, members of the Jamaican working class were predominantly black (of either African or Indian heritage), while members of the employing class (estate owners, merchants, and manufacturers) were largely white (Richards, 2002, p. 341).

The Revival Zionism that emerged from the Christianization of Jamaican blacks continued a form of opposition against, and moral condemnation of, white Christianity for not prohibiting slavery-and therefore Revivalism thrived among the underclasses (Guano, 1994, p. 519). The religious black consciousness movement known as Rastafari took shape in the 1920s and 1930s under the leadership of Marcus Garvey, who denounced the poor treatment of blacks in Jamaica (and in the United States) as he advocated for black nationalism and Pan-Africanism (Boekhout van Solinge, 1996, p. 13). With the accession in Ethiopia of prince Ras Tafari (later crowned Emperor Haile Selassie I), whom they endowed with divinity, Garvey's followers determined to throw off the shackles of British imperial culture, to reappropriate a severed African heritage for the purpose of empowering the underclasses in Jamaican 
society, and to ultimately repatriate to Zion (Africa). During the following century, the Rastafarian movement spread throughout the Caribbean and took hold in Britain, in the United States, and in West Africa. Consequently, the Rastafarian nation is a diverse one, with many leaders, rituals, and religious convictions. Nevertheless, a set of central beliefs binds Rastafarians together: they see "Babylon" as a symbol of decadence and false religions, they find rampant idolatry of other gods appalling, and they condemn corrupting ideas as the enemy of the proper worship of Jah (an abbreviation for "Jehovah"). Rastafarians possess a keen reverence for nature and natural living, and this attitude towards the environment manifests itself in the production of organic foods sometimes grown in self-sufficient cooperatives that harken back to village lifestyles in Africa.

Rastafarians imagine the whole world as potentially part of a single multiracial homeland called Ethiopia, and they believe that cannabis was given to humankind for the "healing of the nations" (Revelation 22:2). They also cite Genesis in support of their veneration of the holy herb: "And the earth brought forth grass, and herb yielding seed after his kind, and the tree yielding fruit, whose seed was in itself, after his kind: and God saw that it was good" (Genesis 1:12). After jettisoning some of the features of Revivalism that initially enthused the group, Rastafarians defined themselves against the status quo as members of an African-Jamaican underclass. The second generation of Rastafarians turned more militant, and they earned the ire of a government blindly following the unenlightened drug policies of the United States. This new generation elevated ganja smoking to a sacred ritual, and Rastafarians spurned razor blades and hair clippers in favor of tangled dreads and unkempt beards. They venerated Haile Selassie, made Ethiopia into the "Promised Land" (Zion), and outlined the key elements of "Rastaology," including "InI consciousness," the philosophy of "livity," and "dread-talk." "InI consciousness" meant realizing one's own divinity; "livity" implied a way of living originating from an understanding that human health results from eating organic foods with which Jah filled the Earth; and dread talk was a means of "chanting down" the social, political, and economic institutions of repression (Edmonds, 2012, p. 45).

For nearly all Rastafarians, cannabis is the supreme herb, and they ingest it as a medicine in tea and food and give it a prominent place in ritual communal activities. According to Jamaican folk belief, cannabis possesses many medical attributes: most notably fortifying the blood, warding off disease, and promoting good health and well-being as a prophylactic and therapeutic. Many cannabis preparations are credited with allowing one to work longer, harder, and faster and with increased overall stamina and vigor. In tea or tonic form, the plant is credited with preventing constipation, treating gonorrhea, curing arthritis, improving vision, and even making children smarter. Resinous flowers find their way into soups and stews, while stalks and leaves are added to teas. Some boil cannabis leaves to make soupbroths, but they are also cooked like spinach and fed to children.
Rastafarians smoke ganja in the form of cigarettes known as "spliffs," but they also "toke" from chillums and water pipes (sacred vessels called "chalices" suggesting the Holy Grail) (Rätsch, 2001, pp. 138-139). While there is no limit to the amount of cannabis they may imbibe, Rastas scorn other intoxicants, including alcohol and manufactured drugs. For most Rastafarians, cannabis is tantamount to the Tree of Life given to human beings by a benevolent creator to ensure good health and mental clarity. According to one of the tradition's mythologies, the hemp plant first grew on the gravesite of Solomon, the wisest person, and therefore it remains irrevocably tied to contemplation and understanding (Rätsch, 2001, p. 138). For Rastafarians too, marijuana leads one out of the false consciousness of Babylon (consumerism, materialism, inequality, injustice, racism, and exploitation) and toward a discovery of the True Self, the divine "I" capable of self-direction (Edmonds, 2012, pp. 4849). Many of these attributes are the same ones by which society may be positively transformed. Given that human society is ultimately a set of relationships-the quality of which reflect our inner selves, as more individuals learn to identify, cultivate, and prolong peak-experiences, we stand to witness considerable social betterment. In becoming aware of "the temporal and the eternal realms in consciousness" by way of peak-experiences, we advance the evolution of our species and move toward "a more peaceful world utopia of some kind” (Richards, 2015, pp. 207-208).

In Toward a Psychology of Being, Maslow observes that "sick individuals make their culture more sick and that healthy individuals make their culture more healthy," therefore improving individual health is "one approach to making a better world" (1968, p. 6). Once their basic needs for safety, belongingness, love, respect, and self-esteem are met, healthy individuals become self-actualized, meaning that they realize their potentials, capacities, and talents (often as a mission call, vocation, fate, or destiny). Selfactualizers also enjoy a higher frequency of peak-experiences and possess superior perceptions of reality, and they exhibit more democratic personality structures, greater autonomy and resistance to cultural norms, heightened detachment and desire for privacy, and they tend to be unusually accepting of self, others, and nature (Ferrara, 2019, p. 125). Because there exists for Maslow "a kind of dynamic parallelism" between the inner and outer, whatever improves one part of a society at any point also tends to improve the rest of society, just as "whatever tends to improve the whole human being tends to improve all other human beings" (1998, p. 125).

\section{CONCLUSION}

While by no means a comprehensive accounting, this brief history of cannabis use in world religions demonstrates its persistence as a mild entheogen deployed in tantum with more traditional religious practices to trigger what Maslow called "peak-experiences," mystical, transcendental, ecstatic, 
epiphanic, salvific moments that constitute the bedrock of human religious experience. Once we have risen to selfactualization, our experiences on other levels are transformed as well, for the lower levels are contained within the higher ones, like a set of Russian dolls (Rowan, 1999, 130). While we never lose our lower level needs completely, they become less influential as we grow beyond the need to derive our esteem from other people or to take from them our status and social role. At every point in the hierarchy, Maslow contends, we have a choice between deficiency motivation and abundance motivation, between safety and growth (Rowan, 1999, 132).

Individuals who move beyond self-actualization to arrive at the top of Maslow's later version of the hierarchy of needs have a strong drive toward self-transcendence through mystical or transpersonal religious experiences (which make them seek identification with something greater than themselves). In formulating a construct of self-transcendence that surpassed self-actualization in his motivational hierarchy, Maslow established a corresponding perspective, transpersonal psychology, "that was intended to go beyond the perspective of human psychology as originally construed" (Koltko-Rivera, 2006, p. 306). Self-transcendent people are motivated by something beyond basic needs, and the inclusion of self-transcendence in Maslow's hierarchy of needs points toward the centrality of peak-experiences to the optimally functioning person, and it permits a richer conception of the meaning and purpose of life (KoltkoRivera, 2006, p. 310). Including a final step of self-transcendence also allows the application of long-standing motivational theories to some aspects of religious practice and experience-and it permits the understanding of how peak-experiences can be positively associated with mental health (Koltko-Rivera, 2006, p. 312).

William Richards at the Johns Hopkins University School of Medicine, who served as Maslow's research assistant from 1966 to 1967, remembers that only an acute cardiac condition kept Maslow from ingesting a psychedelic substance himself, but he was very interested in the rapidly expanding field of psychedelic studies. When asked, Maslow described peak-experiences of his own, "including at least one that had occurred while simply lying on his back in the sunlight in his own backyard" (Richards, 2017, pp. 319-320). Were it not for his heart condition "and the intense controversies raging in academic circles about psychedelic drugs at the time (Leary and Alpert had recently been fired at Harvard), Maslow would have welcomed an opportunity to take mescaline, psilocybin, or LSD" (Richards, 2017, p. 320).

In terms of the role of endogenous cannabinoids and endogenously produced DMT in the human body, and their possible contribution to spontaneously occurring peak-experiences, the endogenous compound anandamide functions in tandem with cannabinoid receptors to produce euphoric feelings similar to those elicited by exogenous cannabinoids such as marijuana (Acharya et al., 2017, 500). The name "anandamide" derives from the Sanskrit word "ananda" (bliss), a designation that emphasizes the role of this compound as an endogenous marijuana-like substance self- delivered by the brain (Scherma et al., 2019, 309). Observations regarding the psychedelic effects of the administration of DMT have led to speculation that endogenous DMT may be involved in imagination and dream states, the maintenance of waking reality, and altered states of consciousness including peak and near-death experiences (Barker, 2018, p. 13). While researchers have puzzled over the biological role of endogenous entheogens for over fifty years, legal restrictions have limited their availability for scientific research, and therefore the function of endogenous hallucinogens such as DMT remains a mystery (Wallach, 2009, 91).

Even so, the human search for chemically enhanced consciousness as a conduit to experiencing the divine is nearly universal in human culture and psychedelics have impacted the development of religion by providing access to alternate states of consciousness conducive to spiritual awakening. These transcendental states fundamentally transform one's understanding of the natural world, and one's place in it, regardless of whether they are evoked through intense travail, religious practice, or the ingestion of chemical agents. Although the historical evidence for the entheogenic use of cannabis can sometimes be difficult to corroborate, it seems clear that the milder and gentler cannabis plant offers access to many of the therapeutic benefits of stronger entheogens, including self-transcendence, when combined with concentrated activities such as meditation, contemplative prayer, fasting, and other spiritual practices.

\section{REFERENCES}

Abel, E. (1980). Marihuana: The first twelve thousand years. New York: Springer.

Acharya, N., Penukonda, S., Shcheglova, T., Hagymasi, A. T., Basu, S., Srivastava, P. K., et al. (2017). Endocannabinoid system acts as a regulator of immune homeostasis in the gut. Proceedings of the National Academy of Sciences of the United States of America, 114(19), 5005-5010. https://doi.org/10.1073/pnas. 1612177114.

Afsahi K., \& Darwich, S. (2016). Hashish in Morocco and Lebanon: A comparative study. International Journal of Drug Policy, 31, 190-198. https://doi.org/10.1016/j.drugpo.2016.02.024.

Aldrich, M. (1977). Tantric cannabis use in India. Journal of Psychedelic Drugs, 9(3), 227-233.

Arie, E., Rosen, B., \& Namdar, D. (2020). Cannabis and frankincense at the Judahite Shrine of Arad. Tel Aviv: Journal of the Institute of Archaeology of Tel Aviv University, 47(1), 1-28. https://doi.org/10.1080/03344355.2020.1732046.

Barker, S. (2018). N, N-dimethyltryptamine (DMT), an endogenous hallucinogen: Past, present, and future research to determine its role and function. Frontiers in Neuroscience, 12(536), 1-17. https://doi.org/10.3389/fnins.2018.00536.

Boekhout van Solinge, T. (1996). Ganja in Jamaica. Amsterdams Drug Tijdschrift, 2, 11-14.

Boesi, A. (2014). Traditional knowledge of wild food plants in a few Tibetan communities. Journal of Ethnobiology and Ethnomedicine, 10, 75. https://doi.org/10.1186/1746-4269-10-75. 
Booth, M. (2005). Cannabis: A history. New York: Picador.

Boyce, M. (2002). Zoroastrians: Their religious beliefs and practices. London: Routledge.

Brown K., \& Cullen, C. (2006). Maslow's hierarchy of needs used to measure motivation for religious behavior. Mental Health, Religion \& Culture, 9(1), 99-108. https://doi.org/10.1080/ 13694670500071695.

Bryant, E. (2001). The quest for the origins of Vedic culture: The Indo-Aryan migration debate. Oxford: Oxford University Press.

Bynum, E. (2012). The African unconscious: Roots of ancient mysticism and modern psychology. New York: Teachers College Press.

Campos-Costero, I. (2006). Marijuana, madness, and modernity in global Mexico, 1545-1920. (Unpublished doctoral dissertation). Harvard University, Cambridge, MA.

Clarke, R., \& Merlin, M. (2013). Cannabis: Evolution and ethnobotany. Berkeley: University of California Press.

Deirdre, D. (1995). Rule Britannia: Women, empire, and Victorian writing. Ithaca, NY: Cornell University Press.

Delle, J. (2014). The colonial Caribbean: Landscapes of power in Jamaica's plantation system. Cambridge: Cambridge University Press.

Diaz, J. (1977). Ethnopharmacology of sacred psychoactive plants used by the Indians of Mexico. Annual Review of Pharmacology and Toxicology, 17(1), 647-675.

Doniger, W. (1981). The Rig Veda: An anthology. New York: Penguin.

Du Toit, B. (1975). Dagga: The history and ethnographic setting of cannabis sativa in southern Africa. In V. Rubin (Ed.) Cannabis and culture (pp. 81-116). Paris: Mouton.

Duncan, M. (2011). Understanding hospitality house guests' needs: A brief case report. Journal of Pediatric Nursing, 26, 332-333. https://doi.org/10.1016/j.pedn.2010.04.006.

Duvall, C. (2014). Cannabis. London: Reaktion.

Duvall, C. (2019). The African roots of marijuana. Durham, NC: Duke University Press.

Edmonds, E. (2012). Rastafari: A very short introduction. Oxford: Oxford University Press.

Eliade, M. (1964). Shamanism: Archaic techniques of ecstasy. Princeton, NJ: Princeton University Press.

Eliade, M. (1982). A history of religious ideas: From Gautama Buddha to the triumph of Christianity. Chicago: University of Chicago Press.

Ferrara, M. (2016). Sacred bliss: A spiritual history of cannabis. Lanham, MD: Rowman \& Littlefield.

Ferrara, M. (2019). New seeds of profit: Business heroes, corporate villains, and the future of American capitalism. Lanham, MD: Lexington Books.

Foltz, R. (2013). Religions of Iran: From prehistory to the present. London: One World.

Frawley, D. (2001). The Rig Veda and the history of India. New Delhi: Aditya Prakashan.

Fürniss, S. (2014). Diversity in Pygmy music. In B. S. Hewlett (Ed.) Hunter-Gatherers of the Congo Basin: Cultures, histories, and biology of African Pygmies (pp. 187-218). London: Transaction.

Glosecki, S. (2004). Defining the dream doctor. In A. A. Znamenski (Ed.) Shamanism: Critical concepts in sociology (Vol. 3, pp. 186242). New York: Routledge.
Godlaski, T. (2012). Shiva, lord of bhang. Substance Use \& Misuse, 47(10), 1067-1072.

Griffith, R, \& Abhimanvu, M. L. (1962). Hymns of the Atharva-Veda: Volume one. Varanasi: Master Khelari Lal \& Sons.

Guano, E. (1994). Revival Zion. An Afro-Christian religion in Jamaica. Anthropos, 89, 517-552.

Hamid, A. (2002). The ganja complex: Rastafari and marijuana. Lanham, MD: Lexington Books.

Hutchinson, H. (1975). Patterns of marihuana use in Brazil. In V. Rubin (Ed.) Cannabis and culture (pp. 195-206). Paris: Mouton.

Khalifa, A. (1975). Traditional patterns of hashish use in Egypt. In V. Rubin (Ed.) Cannabis and culture (pp. 195-205). Paris: Mouton.

Koltko-Rivera, M. (2006). Rediscovering the later version of Maslow's hierarchy of needs: Self- transcendence and opportunities for theory, research, and unification. Review of General Psychology, 10(4), 302-317. https://doi.org/10.1037/1089-2680.10.4.302.

Kuddus, M., Ginawi, I., \& Al-Hazimi, A. (2013). Cannabis sativa: An ancient wild edible plant of India. Emirates Journal of Food and Agriculture, 25(10), 736-745. https://doi.org/10.9755/ejfa. v25i10.16400.

Lee, M. (2013). Smoke signals: A social history of marijuana: Medical, recreational, and scientific. New York: Scribner.

Long, T., Wagner, M., Demske, D., Leipe, C., \& Tarasov, P. E. (2017) Cannabis in Eurasia: Origin of human use and Bronze Age trans-continental connections. Vegetation History and Archaeobotany, 26(2), 245-258.

Luke, D., \& Kittenis, M. (2005). A preliminary survey of paranormal experiences with psychoactive drugs. Journal of Parapsychology, 69(2), 305-327.

Maslow, A. H. (1954). Motivation and personality. New York: Harper \& Bros.

Maslow, A. (1964). Religions, values, and peak-experiences. Columbus: Ohio State University Press.

Maslow, A. (1968). Toward a psychology of being. New York: Van Nostrand Reinhold.

Maslow, A. (1971). The farther reaches of human nature. New York: Penguin.

Maslow, A. (1998). Maslow on management. New York: Wiley and Sons.

McKenna, T. (1992). The food of the gods. New York: Bantam.

McRae, E. (1998). Santo Daim and Santa Maria-The licit ritual use of ayabuasca and the illicit use of cannabis in a Brazilian Amazonian religion. International Journal of Drug Policy, 9, 325-338.

Meulenbeld, G. (1989). The search for clues to the chronology of Sanskrit medical texts, as illustrated by the history of bhanga (Cannabis sativa Linn.). Studien zur Indologie und Iranistik, 15, 59-70.

Milani, M. (2013). Sufism in the secret history of Persia. Durham, NC: Acumen.

Mitchell, P., \& Hudson, A. (2004). Psychoactive plants and southern African hunter-gatherers: A review of the evidence. South African Humanities, 16, 39-57.

Olupona, J. (2014). African religions: A very short introduction. Oxford: Oxford University Press. 
Orzech, C. (2011). Esoteric Buddhism and the Tantras in East Asia. Leiden: Brill.

Owen, S. (1996). Foreward. In The book of songs (Arthur Waley, Trans.). New York: Grove.

Péri, B. (2016). 'It is the Weed of Lovers': The use of cannabis among Turkic peoples up to the 15th century. Acta Orientalia Academiae Scientiarum Hungaricae, 69(2), 139-155. https:// doi.org/10.1556/062.2016.69.2.2.

Ramzy, C. (2017). Singing heaven on earth: Coptic counterpublics and popular song at Egyptian mulid festivals. International Journal of Middle East Studies, 49(3), 375-394. https://doi.org/ 10.1017/S0020743817000290.

Rätsch, C. (2001). Marijuana medicine: A world tour of the healing and visionary powers of cannabis. Rochester: Healing Arts Press.

Richards, G. (2002). Race, class, and labour politics in colonial Jamaica. In K. Monteith, \& G. Richards (Eds.) Jamaica in slavery and freedom: History, heritage and culture (pp. 340362). Kingston: University of the West Indies Press.

Richards, W. (2015). Sacred knowledge: Psychedelics and religious experiences. New York: Columbia University Press.

Richards, W. (2017). Abraham Maslow's interest in psychedelic research: A tribute. Journal of Humanistic Psychology, 57(4), 319-322. https://doi.org/10.1177/0022167816670997.

Robinson, A. (2014). India: A short history. London: Thames and Hudson.

Rosenthal, F. (1971). The herb: Hashish versus medieval Muslim society. Leiden: Brill.

Rowan, J. (1999). Ascent and descent in Maslow's theory. Journal of Humanistic Psychology, 39(3), 125-133. https://doi.org/10.1177/ 0022167899393010.

Ruck, C., Hoffman, M., \& Celdrán, J. (2011). Mushrooms, myth, and Mithras: The drug cult that civilized Europe. San Francisco, CA: City Lights Bookstore.

Russo, E., Jiang, H. E., Li, X., Sutton, A., Carboni, A., Del Bianco, F., et al. (2008). Phytochemical and genetic analyses of ancient cannabis from Central Asia. Journal of Experimental Botany, 59(15), 4171-4182. https://doi.org/10.1093/jxb/ern260.

Samuel, G. (2008). The origins of Yoga and Tantra: Indic religions to the thirteenth century. Cambridge: Cambridge University Press.

Scherma, M., Masia, P., Satta, V., Fratta, W., Fadda, P., Tanda, G., et al. (2019). Brain activity of anandamide: A rewarding bliss? Acta Pharmacologica Sinica, 40(3), 309-323. https://doi.org/10. 1038/s41401-018-0075-x.

Scott, D. and Evans, J. (2010). Peak experience project. International Journal of Children's Spirituality, 15(2), 143-158. https:// doi.org/10.1080/1364436X.2010.497648.

Sofowora, A. (1982). Medical plants and traditional medicine in Africa. New York: John Wiley and Sons.

Steindl-Rast, D. (2014). Psychoactive substances and sacred values: Reconsidering Abraham Maslow's discoveries. In J. Harold Ellens (Ed.), Seeking the sacred with psychoactive substances: Chemical paths to spirituality and to God (pp. 381-394). Santa Barbara: Praeger.

Touw, M. (1981). The religious and medical uses of cannabis in China, India, and Tibet. Journal of Psychoactive Drugs, 13(1), 23-34. https://doi.org/10.1080/02791072.1981.10471447.

Waley, A. (1996). The book of songs. New York: Grove.

Wallach, J. (2009). Endogenous hallucinogens as ligands of the trace amine receptors: A possible role in sensory perception. Medical Hypotheses, 72(1), 91-94. https://doi.org/10.1016/j. mehy.2008.07.052.

Warf, B. (2014). High points: An historical geography of cannabis. Geographical Review, 104(4), 414-438.

Watts, A. (2013). The joyous cosmology: Adventures in the chemistry of consciousness. New York: New World.

Williams-Garcia, R. (1975). The ritual use of cannabis in Mexico. In V. Rubin (Ed.) Cannabis and culture (pp. 133-146). Paris: Mouton.

Znamenski, A. (2007). The beauty of the primitive: Shamanism and Western imagination. Oxford: Oxford University Press. 